\title{
HOW SMART IS THE MOBILITY OF CROATIAN CITIZENS? BEHAVIOUR PATTERNS OF LOCAL POPULATION AS AN INDICATOR OF TOURIST DESTINATION TRANSPORTATION SUPPLY
}

\author{
Nataša Slavić \\ Edna Mrnjavac
}

https://doi.org/10.20867/tosee.05.24

\begin{abstract}
Purpose - The purpose of this paper is to analyse and determine the mobility patterns of Croatian citizens in order to evaluate the current momentum of transportation supply. The traffic behaviour and attitudes of the local population derive from the quality of the same traffic system that is the basis of the tourist (transportation) experience in urban destinations.

Methodology - This research follows the methodology previously used by the European Commission in studying the opinions and behaviour of traffic participants in the EU - Special Eurobarometer 422a "Quality of transport" that also included respondents from Croatia. Data were gathered by the interview method, and the results are structured to this paper's specific context in order to better assess the mobility weaknesses and potential in Croatian urban tourist destinations. The sample of Croatian respondents is significantly larger $(n=2834$, in comparison with $n=1084$ in the 2014 EU study) and the findings are therefore better informed.

Findings - The actual mobility patterns and related traffic system supply imply shortcomings in the mobility management of Croatian urban tourist destinations. In 2018 mobility patterns of Croatian respondents suggest underutilized mobility management options (e.g. lack of automobile usage restrictions, lack of available alternatives) - both from the perspectives of destination accessibility and mobility. The average respondent's mobility pattern is far from ideal.

Contribution - Identifying mobility patterns of Croatian citizens is the initial stage in determining the effect of transportation system supply (and management) on tourist travel patterns (to be further explored in the next stages of a scientific project). At the time of submission of this paper, there has been no new Eurobarometer on the topic of the quality of transport, since the 2014 survey so the contribution of this paper is in pinpointing the behaviour of Croatian citizens - specifically their daily mobility and longer travel patterns. By putting the identified mobility patterns in relation to perceived traffic system supply, this paper discusses the potential effects of current momentum in Croatian transportation system on tourist behaviour in urban destinations.

Keywords mobility management; 'smart' mobility; mobility in urban tourist destinations; patterns of traffic behaviour; citizens' attitudes toward mobility
\end{abstract}

\section{INTRODUCTION}

Cities are rapidly evolving and, with nearly 1.5 million people becoming urban dwellers, lack the capacity and resources to ensure a sustainable urban development (World Economic Forum 2017). The booming urban population challenges mobility. As the world continues to urbanize, sustainable development depends increasingly on the successful management of urban growth - with efficient and sustainable transportation 
ToSEE - Tourism in Southern and Eastern Europe, Vol. 5, pp. 621-640, 2019

N. Slavić, E. Mrnjavac: HOW SMART IS THE MOBILITY OF CROATIAN CITIZENS? BEHAVIOUR ...

systems being the key to the quality of life in urban areas (due to enabling "smart mobility").

European transport policy fosters cross-border long-distance mobility (Trans-European Transport Network) and provides transport infrastructure funding. Nevertheless, urban mobility is primarily considered a local issue in line with the subsidiarity principle. However, mobility problems are common to most European cities and need to be managed on all levels. Mobility in urban areas facilitates growth and employment in the EU and it is therefore a necessity to enhance mobility while at the same time reducing congestion, accidents and pollution in all European cities. In tracking changes of public opinion on a certain topic EU uses Eurobarometer surveys. Tracing public opinion trends helps the preparation of policy, decision-making, and the evaluation of the EU's work.

The traffic behaviour and attitudes of the local population are inevitably related to the quality of the existing traffic system. The same system is the basis of the tourist (transportation) experience in urban destinations. Managing mobility in tourist destinations requires a systematic approach. Knowledge about actual mobility patterns is crucial in identifying traffic system supply shortcomings. The interdependence of transportation supply and transportation behaviour (tourists included) in urban tourist destinations requires constant research and a demand perspective.

Identifying mobility patterns in urban setting is the first step in evaluating the long-term sustainability of transportation system management in Croatia. This paper has four sections. It starts with the topic background (Theoretical context), followed by the Research and methodology section. The Research results section provides a clear picture of the mobility patterns of Croatian citizens. The section Discussion offers an elaboration on the context (the existing transportation system supply) influencing the identified travel behaviour. Behavioural patterns of local population are used as an indicator of transportation system supply in Croatian urban destinations - an important determinant of tourist transportation behaviour.

\section{THEORETICAL CONTEXT}

\subsection{Sustainable urban mobility}

More than half of the world's population lives in urban areas (Ritchie and Roser 2019; United Nations 2018), and by 2050 it is expected to rise to more than two thirds (World Economic Forum 2017). The quality of urban life and lifestyle greatly depend on an efficient transportation system (Przybylowski 2018). Although it could be argued that cities share a "generic code", the solutions in battling the negative side-effects of cardependant urban living need to be tailored (Priester et al. 2014). An integrated approach on all levels of mobility is considered the only viable option automobile-dependant cities have in battling further quality of life deterioration caused by traffic (European Commission 2016). 
ToSEE - Tourism in Southern and Eastern Europe, Vol. 5, pp. 621-640, 2019

N. Slavić, E. Mrnjavac: HOW SMART IS THE MOBILITY OF CROATIAN CITIZENS? BEHAVIOUR ...

New mobility patterns in urban space require a resource-efficient transport system (European Union 2011), catering for mobility, but also enhancing accessibility (Jones 2014 , 9). Sustainable urban mobility offers an accessible, sustainable, safe, integrated, environmentally friendly and efficient traffic system, able to meet the demands of all (European Commission 2013). European cities try to tackle changing urban mobility (both people movement and transfer of goods) through integrated planning. Implementing Sustainable Urban Mobility Plans (SUMPs) is aimed at "providing highquality and sustainable mobility and transport to, through and within the urban area" and in line with the needs of the "functioning city" (ELTIS 2018a). There are no national guidelines for SUMPs preparation in Croatia (ELTIS 2018b).

Sustainable Urban Mobility is a strategic priority area (European Commission 2016, 18, fig. 1) as part of the "smart, sustainable and inclusive growth" objective of the Europe 2020 Strategy (European Commission 2010). Nevertheless, integrating topics like PT, walking and cycling, intermodality, mobility management, urban logistics etc. is a challenging task in real life conditions (Decker et al. 2012; Okraszewska et al. 2018; Przybylowski 2018). Citizen and stakeholder engagement are an integral part of sustainable mobility planning (Lindenau and Böhler-Baedeker 2014).

Not all cities have the necessary capacity and resources for sustainable development. Although aimed at managing various (but potentially all) areas of residents' urban activities, the concept of sustainable (smart) transportation inevitably affects tourists and tourism in a destination as well.

\subsection{Managing mobility}

Mobility Management (MM) and Transportation Demand Management (TDM) could be considered synonyms based on the same fundamental tenant - influencing individual travel behaviour by a number of measures available to transport professionals as means of reducing the demand for drive-alone private cars (reducing the negative effects of cardominance) and promoting alternative mobility options at the same time. The so-called carrot and stick approach (Meyer 1999) has been implemented since the 1970s (Enoch $2012,20)$ and the reality of unsustainable urban growth makes it contemporary.

The evolution of urban mobility implies a periodical reinterpretation of the notion and its focus. A 'socio-technical' or 'activity-based' perspective on mobility emphasizes reduced car use and reallocating road space to sustainable transport modes and street activities, encouraging alternatives to automobile travel (PT, walking, cycling) and promoting liveable cities (Jones 2014). Tourist transportation demand multiplies urban transportation issues.

Tourists expect uninterrupted movement, just as residents do. Urban mobility management actions affect both the conflicts in street circulation as well as the preservation of the attraction sites (IPHAN 1997 as cited in Dias et al. 2014). Tourism transportation planning requires a complementary role of public and private stakeholders in managing tourism transportation infrastructure (Cheuk et al. 2010; Kaldiyarov et al 2017) and effectively using national/regional resources in tourism. The quality and performance of transportation systems (integrated, reliable, safe, information-based, 
ToSEE - Tourism in Southern and Eastern Europe, Vol. 5, pp. 621-640, 2019

N. Slavić, E. Mrnjavac: HOW SMART IS THE MOBILITY OF CROATIAN CITIZENS? BEHAVIOUR ...

characterized by type-variety and an adequate level of transportation system management) support tourism development (Marlina and Natalia 2017). Transportation needs of international tourists are met by accessibility-based transport planning (Nutsugbodo et al. 2018). Sustainable tourism and sustainable mobility (implying not only changes of behaviour i.e. mode choice, but also reduced mobility) are interconnected (Hoyer 2000).

\subsection{Travel behaviour}

Understanding behaviour patterns is key in managing transportation demand. Academic research recognizes a variety of approaches (e.g. Alkay 2011; Axhausen 2007; Cheng et al. 2019; Palma Lima et al. 2014) in effectively responding to diversified mobility needs. The shift towards more sustainable transportation and shared mobility is gradual and slow (Kamargianni et al. 2016; Zavaglia 2016) and requires changes in transportation services - analysing and managing "causative factors" like population growth, aging or income (Cheba and Saniuk 2016). 'Greening' urban travel patterns implies eco-mobility strategies implementation (e.g. transit-oriented development, active mobility, integrated pricing schemes etc.) (Jason Chang and Hsu 2014).

The combining of technological developments and social capital while implementing different mobility and transportation system management measures is at the centre of attempts to influence changes in transportation behaviour. Using mobile phone data in transportation research (Wang et al. 2018) offers unique features in advancing knowledge on individual mobility patterns (Calabrese et al. 2013; Gonzales et al. 2008). In fact, such activity-tracking type of data could stimulate more sustainable mobility patterns by providing "eco-feedback" on personal mobility (Bucher et al. 2019). The assessment of sustainability of urban mobility should also include cultural indicators (Macedo et al. 2017), as cultural and social factors are found to have a major role in transportation behaviour (Cheba and Saniuk 2016). Urban mobility could be assessed through sentiment analysis of social media content (Serna et al. 2017) or social responsibility (Grieco 2015) as well, having in mind that group travel behaviour differs from individual in terms of both time and space (Zhang et al. 2018). New urban development (new types of urban living) is found to influence daily mobility patterns (Jarass and Heinrichs 2014) as well.

Individual travel behaviour change is based on informed choices and a "supportive" transportation system, with "soft" measures at its core (European Platform on Mobility Management (EPOMM) n.d.), also known as the "communicative" measures (Fujii and Taniguchi 2006). More recently, the Mobility as a Service (MaaS) concept has emerged as an innovative tool in tackling urban mobility issues and modifying travel behaviour towards integrated transportation and seamless door-to-door mobility (Kamargianni et al. 2016).

Tourism transportation supply is based on each destination's transportation system (implying both infrastructure and transportation services). Identifying the mobility (travel) patterns of the local population enables evaluating the current state of transportation supply also available to a destination's visitors. Research results on the 
ToSEE - Tourism in Southern and Eastern Europe, Vol. 5, pp. 621-640, 2019

N. Slavić, E. Mrnjavac: HOW SMART IS THE MOBILITY OF CROATIAN CITIZENS? BEHAVIOUR ...

transportation behaviour patterns of Croatian citizens are presented in the following section.

\section{RESEARCH AND METHODOLOGY}

There is a number of ways that the European Commission is dealing with or affecting transportation, whether through strategic documents (like Europe 2020 (European Commission 2010) or the White Paper on transport (European Commission 2011)), specific specialized interest groups (like the European Cycling Federation), or a variety of transport-related projects or web-platforms (like ELTIS).

European transport policy fosters cross-border long-distance mobility (Trans-European Transport Network) and provides transport infrastructure funding (ECF, 2019). Nevertheless, urban mobility is primarily considered a local issue in line with the subsidiarity principle. However, mobility problems are common to most European cities and need to be managed on all levels. Mobility in urban areas facilitates growth and employment in the EU (European Commission, 2019a) and it is therefore a necessity to enhance mobility while at the same time reducing congestion, accidents and pollution in all European cities. In tracking changes of public opinion on a certain topic EU uses Eurobarometer surveys (European Commission, 2019b). Tracing public opinion trends helps the preparation of policy, decision-making, and the evaluation of the EU's work. Periodical research on transportation issues provides adequate data on the transportation behaviour, attitudes and opinions of Europeans. This paper is based on one such Eurobarometer survey. On behalf of the European Commission's Directorate General for Mobility and Transport (aimed at promoting efficient, safe and sustainable transport solutions) TNS Opinion \& Social Network carried out the survey whose results are used as a reference point for this research - Special Eurobarometer 422a „Quality of Transport".

This Special Eurobarometer was carried out in October 2014, with 27.868 respondents interviewed in total, face-to-face at home in their mother tongue. The methodology used is that of Eurobarometer surveys (TNS Opinion \& Social Network 2014, p. 4). There was an earlier attempt to analyse the mobility attitudes and experiences of Croatian citizens (Mrnjavac and Slavić 2018), but the research differed in scope and focus.

Implementing the existing approach, previously used by the European Commission in studying Quality of Transport in EU (Croatia included), data were gathered through interviews. The survey questions were replicated from the Special Eurobarometer (TNS Opinion \& Social Network 2014) in order to ensure comparability. They were translated into Croatian for the purpose of targeting Croatian citizens, aged 18 years and over, living in urban destinations.

While the Eurobarometer's sample size for Croatia $(\mathrm{N}=1084)$ was considered adequate in relation to population size, the sample in this research $(\mathrm{N}=2384)$ is considered adequate for the purpose of drawing informed conclusions with a certain probability. The sample design is a convenience one due to the method of execution - the interviews were conducted by specially instructed undergraduate students. 
ToSEE - Tourism in Southern and Eastern Europe, Vol. 5, pp. 621-640, 2019

N. Slavić, E. Mrnjavac: HOW SMART IS THE MOBILITY OF CROATIAN CITIZENS? BEHAVIOUR ...

All interviews were conducted face to face in people's homes between March and June 2018, applying the same (Eurobarometer) questions and noting the answers. Data were compiled, proof checked and later coded and analysed.

\section{RESEARCH RESULTS: PATTERNS OF TRANSPORTATION BEHAVIOUR OF CROATIAN CITIZENS}

\subsection{The respondents' profile}

Although the sample is geographically diversified, the majority of respondents are from Primorje and Gorski Kotar County (31\%), followed by the City of Zagreb and Zagreb County (30\%). The average age of the respondents is approximately 33 years, with the oldest respondent being 90. Somewhat less than half of the respondents $(47 \%)$ are employed and about one third $(36 \%)$ are students. More detailed profile is in table 1.

\section{Table 1: The profile of interviewed Croatian citizens}

\begin{tabular}{|l|c|c|c|c|c|c|c|}
\hline \multicolumn{1}{|c|}{ county } & $\begin{array}{c}\text { no. of } \\
\text { responde- } \\
\text { nts }\end{array}$ & $\begin{array}{c}\text { sample } \\
\text { share (\%) }\end{array}$ & $\begin{array}{c}\text { stude- } \\
\text { nt (\%) }\end{array}$ & $\begin{array}{c}\text { emplo- } \\
\text { yed (\%) }\end{array}$ & $\begin{array}{c}\text { unemplo- } \\
\text { yed (\%) }\end{array}$ & $\begin{array}{c}\text { reti- } \\
\text { red } \\
(\%)\end{array}$ & $\begin{array}{c}\text { avg. } \\
\text { age }\end{array}$ \\
\hline $\begin{array}{l}\text { Primorje and } \\
\text { Gorski kotar }\end{array}$ & 880 & 31,05 & 34 & 49 & 8 & 9 & 33,6 \\
\hline $\begin{array}{l}\text { City of Zagreb } \\
\text { and Zagreb }\end{array}$ & 858 & 30,28 & 37 & 48 & 8 & 7 & 32,5 \\
\hline Istria & 287 & 10,13 & 39 & 46 & 7 & 7 & 33,4 \\
\hline $\begin{array}{l}\text { Krapina and } \\
\text { Zagorje }\end{array}$ & 159 & 5,61 & 28 & 52 & 11 & 9 & 33 \\
\hline $\begin{array}{l}\text { Sisak and } \\
\text { Moslavina }\end{array}$ & 87 & 3,07 & 30 & 46 & 16 & 8 & 33 \\
\hline Karlovac & 75 & 2,65 & 25 & 46 & 17 & 12 & 34,7 \\
\hline Varaždin & 69 & 2,43 & 38 & 49 & 9 & 4 & 27,7 \\
\hline $\begin{array}{l}\text { Koprivnica and } \\
\text { Križevci }\end{array}$ & 66 & 2,33 & 47 & 39 & 5 & 9 & 32,7 \\
\hline $\begin{array}{l}\text { Split and } \\
\text { Dalmatia }\end{array}$ & 64 & 2,26 & 34 & 42 & 14 & 9 & 34,7 \\
\hline Other counties & 289 & 10,20 & 39 & 41 & 11 & 9 & 31,1 \\
\hline \multicolumn{1}{|c|}{ total } & $\mathbf{2 8 3 4}$ & $\mathbf{1 0 0}$ & $\mathbf{3 6}$ & $\mathbf{4 7}$ & $\mathbf{9}$ & $\mathbf{8}$ & $\mathbf{3 2 , 6}$ \\
\hline
\end{tabular}

The respondents' everyday mobility and travel patterns are analysed in the following sections

\subsection{Everyday mobility behaviour}

The preferred mobility choice for commuting and everyday activities for the majority of Croatian residents (47\%) is their own car. Public transport (PT) was used by approximately a quarter of respondents in 2018 (26\%). Walking is chosen by almost one in five respondents (19\%) (graph 1). Everyday travel patterns and the transport mode choice are primarily motivated by speed $(45 \%)$ and convenience $(45 \%)$. The influence 
ToSEE - Tourism in Southern and Eastern Europe, Vol. 5, pp. 621-640, 2019

N. Slavić, E. Mrnjavac: HOW SMART IS THE MOBILITY OF CROATIAN CITIZENS? BEHAVIOUR ...

of the option "there is no alternative" on travel behaviour is also significant (27\%), unlike the weak influence of the factors "environment" $(7 \%)$ and "security" (4\%) (table 4).

The determinants of everyday mode choice change to an extent when only the caroriented respondents are analysed. Speed is an important factor for as much as $70 \%$, and convenience, for $61 \%$. Significantly, approx. one fifth (19\%) have no other alternative.

\section{Graph 1: The mode choice for everyday mobility}

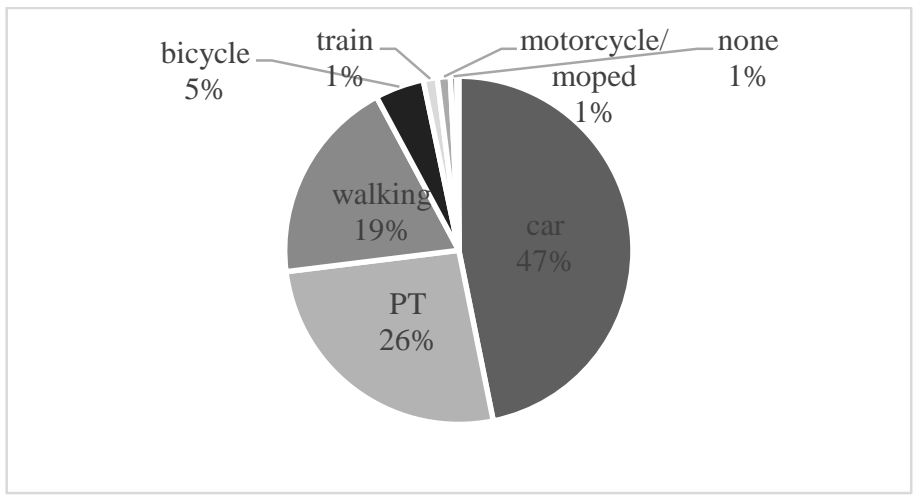

In 2018, ticket price (56\%) and service frequency (46\%) were the most significant barriers to PT usage. Service reliability and punctuality (24\%) is becoming an issue of PT as well, in addition to PT coverage (26\%) (graph 2).

Graph 2: Factors that would encourage the (more frequent) use of public transport

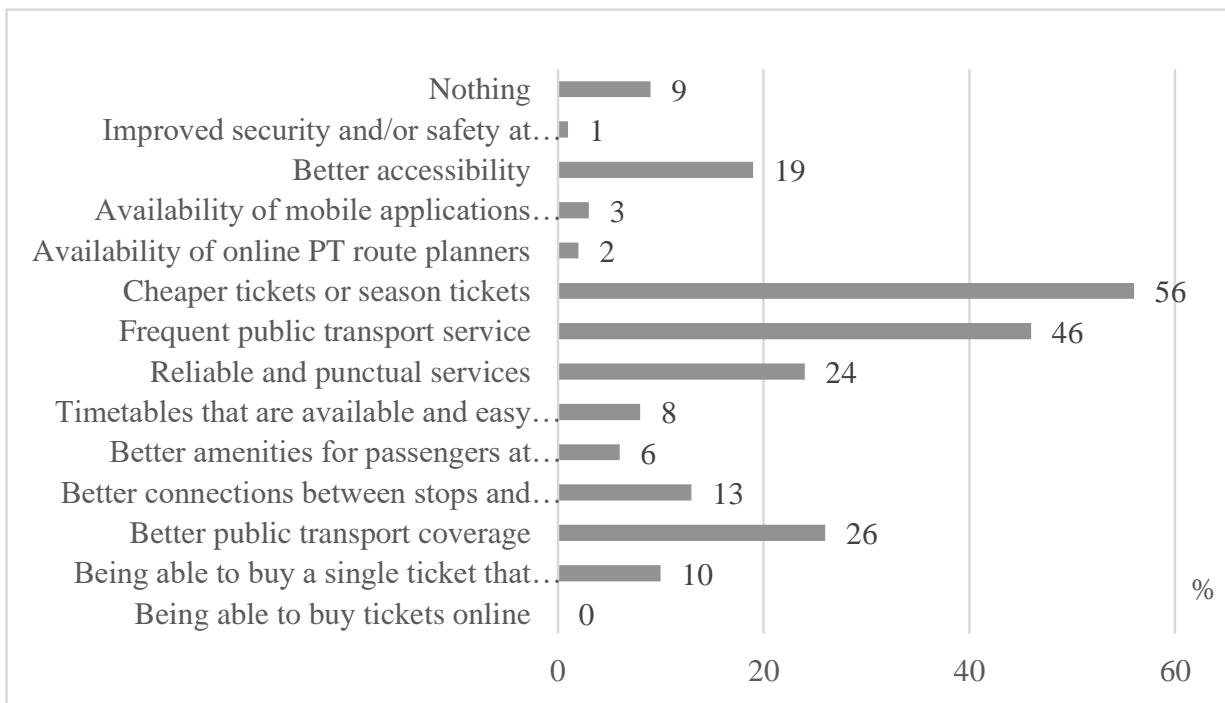

Travel on longer distances (including tourism-motivated travel) recognizes certain similarities to the presented findings on everyday mobility. 
ToSEE - Tourism in Southern and Eastern Europe, Vol. 5, pp. 621-640, 2019

N. Slavić, E. Mrnjavac: HOW SMART IS THE MOBILITY OF CROATIAN CITIZENS? BEHAVIOUR ...

\subsection{Travel behaviour}

Research results indicate that Croatian citizens travelled a fair amount in 2018. when looking at journeys of $300 \mathbf{~ k m}$ and more. Almost one third (31\%) travelled 4 or more times within the EU in 2018. The respondents mostly used their car on these journeys $(67 \%)$. The modal share of planes $(7 \%)$, trains $(3 \%)$ and ships $(0 \%)$ is incomparably smaller (graph 3). Extracting only the data on the behaviour of respondents who primarily use cars for everyday movement, the analysis shows an even bigger dominance of road traffic modes in journeys of $300 \mathrm{~km}$ and more. This segment of respondents uses mostly cars $(82 \%)$, while coaches are their second choice $(11 \%)$, followed by planes $(5 \%)$ and trains $(1 \%)$.

Graph 3: The mode of transport used the last time respondents made a journey of $300 \mathrm{~km}$ or more

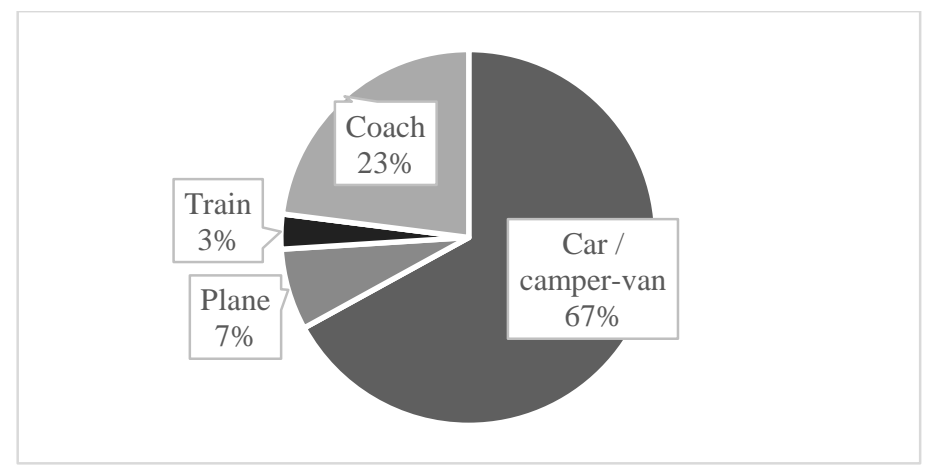

The main reason for transportation choice on journeys longer than $300 \mathbf{~ k m}$ is speed (56\%), followed by convenience (50\%). The cost of travel $(26 \%)$ is also one of the major determinants of travel behaviour, as well as lacking alternatives (19\%).

As far as the characteristics of journeys of $300 \mathbf{~ k m}$ or more are concerned, the journeys were considered value for money by (only) 2/3 of respondents in 2018. An almost identical split between positive and negative attitude is identified in sufficient amenities for passengers. Most of the respondents think that their travel lasted as planned (68\%). Safety was not an issue for $95 \%$ of Croatian residents (table 2). It is worth noting that this perception has changed to a certain extent in relation to the 2014 study (TNS Opinion \& Social Network 2014), and it has a slightly negative character. 
ToSEE - Tourism in Southern and Eastern Europe, Vol. 5, pp. 621-640, 2019

N. Slavić, E. Mrnjavac: HOW SMART IS THE MOBILITY OF CROATIAN CITIZENS? BEHAVIOUR ...

Table 2: The characteristics of the respondents' last journey of $300 \mathbf{~ k m}$ or more $(\%)$

\begin{tabular}{|l|c|c|c|c|}
\hline & Year & Yes & No & $\begin{array}{c}\text { Don't } \\
\text { know }\end{array}$ \\
\hline \multirow{2}{*}{ The journey was good value for money } & 2014 & 95 & 3 & 2 \\
\cline { 2 - 5 } & 2018 & 65 & 18 & 16 \\
\hline $\begin{array}{l}\text { There were enough amenities for } \\
\text { passengers }\end{array}$ & 2014 & 91 & 6 & 3 \\
\hline $\begin{array}{l}\text { Travelling did not take longer than } \\
\text { planned }\end{array}$ & 2018 & 64 & 18 & 17 \\
\hline \multirow{2}{*}{ The journey was safe } & 2014 & 79 & 20 & 1 \\
\cline { 2 - 5 } & 2018 & 68 & 22 & 9 \\
\hline
\end{tabular}

A considerable number of respondents chose the statement "stayed the same", regardless of the transportation sector, in assessing the quality of individual transportation subsystems in Croatia in the last 5 years (table 3). In road transport, the perception is prevailingly positive (total "Improved" 70\%; total "Deteriorated" 8\%). There is evidence of a large part of Croatian citizens not using air (30\%) and sea/river transport services (43\%), thus being unable to assess their quality. Nevertheless, the quality of these transportation subsystems is still perceived as more improved than deteriorated, when those respondents unable to provide an answer are excluded from analyses. Forty-four per cent of the respondents think air transport has improved (3\% think it has deteriorated), and $18 \%$ consider that sea/river transport improved, as opposed to $6 \%$ who think it has deteriorated in quality.

Table 3: Transportation sectors quality (services, connections, infrastructure, etc.) in Croatia in the last 5 years $(\%)$

\begin{tabular}{|l|c|c|c|c|c|c|}
\hline & $\begin{array}{c}\text { Impro- } \\
\text { ved a lot }\end{array}$ & $\begin{array}{c}\text { Somewhat } \\
\text { improved }\end{array}$ & $\begin{array}{c}\text { Somewhat } \\
\text { deterio- } \\
\text { rated }\end{array}$ & $\begin{array}{c}\text { Deteriorate } \\
\text { d a lot }\end{array}$ & $\begin{array}{c}\text { Stayed } \\
\text { the same }\end{array}$ & $\begin{array}{c}\text { Don't } \\
\text { know }\end{array}$ \\
\hline $\begin{array}{l}\text { Air } \\
\text { transport }\end{array}$ & 10 & 34 & 2 & 1 & 23 & 30 \\
\hline $\begin{array}{l}\text { Rail } \\
\text { transport }\end{array}$ & 1 & 10 & 22 & 19 & 25 & 22 \\
\hline $\begin{array}{l}\text { Road } \\
\text { transport }\end{array}$ & 22 & 48 & 5 & 3 & 20 & 2 \\
\hline $\begin{array}{l}\text { Sea/river } \\
\text { transport }\end{array}$ & 1 & 17 & 4 & 2 & 33 & 43 \\
\hline
\end{tabular}

Perceived travel cost (70\%) and lack of travel options (53\%) from the closest airport are identified as the most serious problems affecting air transport in Croatia (graph 4). This is followed by the lack of airports (29\%), indicating air traffic supply shortcomings that Croatian citizens face when taking journeys longer than $300 \mathrm{~km}$. 
ToSEE - Tourism in Southern and Eastern Europe, Vol. 5, pp. 621-640, 2019

N. Slavić, E. Mrnjavac: HOW SMART IS THE MOBILITY OF CROATIAN CITIZENS? BEHAVIOUR ...

\section{Graph 4: The most serious problems affecting air transport in Croatia}

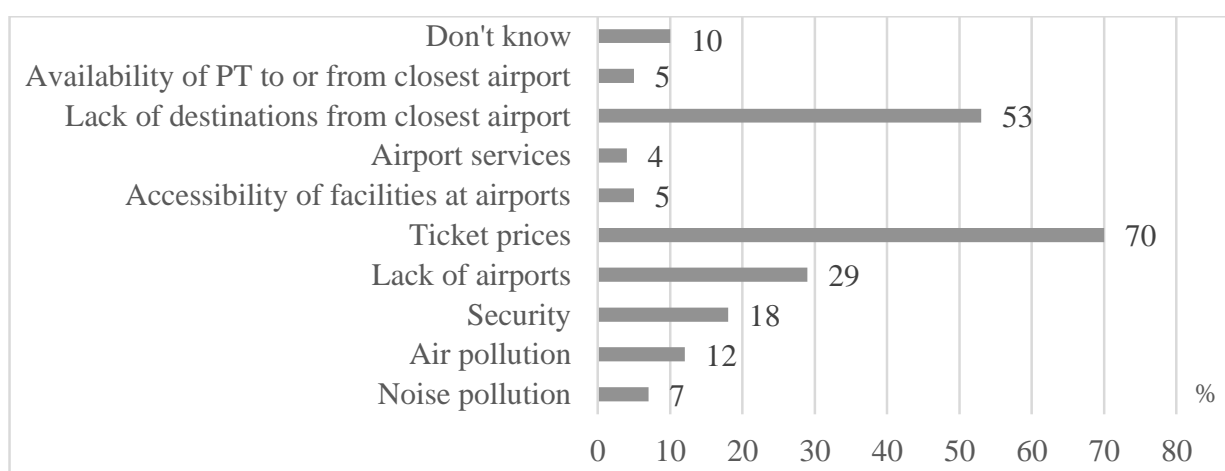

After more than a decade of ban on liquids on board planes, half of the respondents stated that the ban is not important (total 51\%) for their travel choice, but $36 \%$ think the opposite.

Rail transport is perceived as the worst of the travel modes and this perception reflects the stagnation in the sector. Croatian citizens consider rail maintenance $(45 \%)$, travel speed (i.e. lack of high-speed lines, $44 \%$ ), missing links (36\%), service reliability (35\%) and quality of on-board services and facilities (29\%) the most serious problems affecting rail transport in Croatia (graph 5).

\section{Graph 5: The most serious problems affecting rail transport in Croatia}

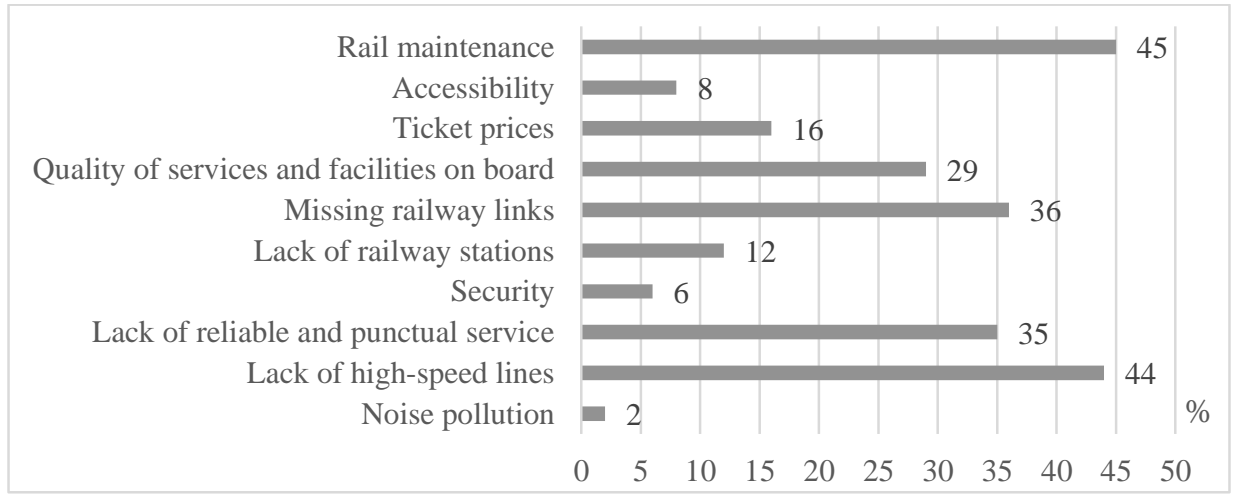

The perception of road transport problems in Croatia is a bit different from other traffic sectors (graph 6). The focus is not so much on the missing links, as on road congestion $(73 \%)$, road maintenance $(58 \%)$ and security $(39 \%)$. 
ToSEE - Tourism in Southern and Eastern Europe, Vol. 5, pp. 621-640, 2019

N. Slavić, E. Mrnjavac: HOW SMART IS THE MOBILITY OF CROATIAN CITIZENS? BEHAVIOUR ...

\section{Graph 6: The most serious problems affecting roads in Croatia}

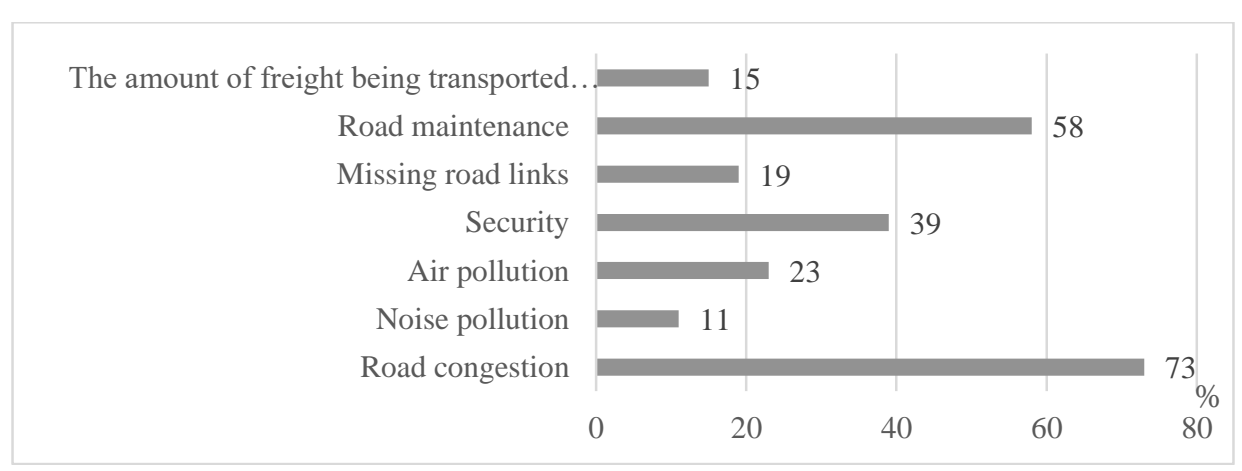

Priorities for improving safety on roads in Croatia are ranked by the respondents as: 1) improved road maintenance $(64 \%)$; 2) zero alcohol tolerance $(57 \%)$; 3) stricter speed limits $(37 \%)$; 4) stricter control on use of electronic devices while driving $(36 \%)$; 5) more training for drivers $(19 \%)$; 6) easy and timely access to travel information when travelling (17\%); and 7) frequent police controls (16\%). To have their vehicles online to allow for the better traffic management and make their journeys easier and safer is acceptable to $73 \%$ of citizens, although mostly under certain conditions (64\%).

Missing transport links (45\%) and transportation cost $(36 \%)$ are the most serious problems affecting water-based transport in Croatia in 2018 (graph 7).

\section{Graph 7: The most serious problems affecting sea/river transport in Croatia}

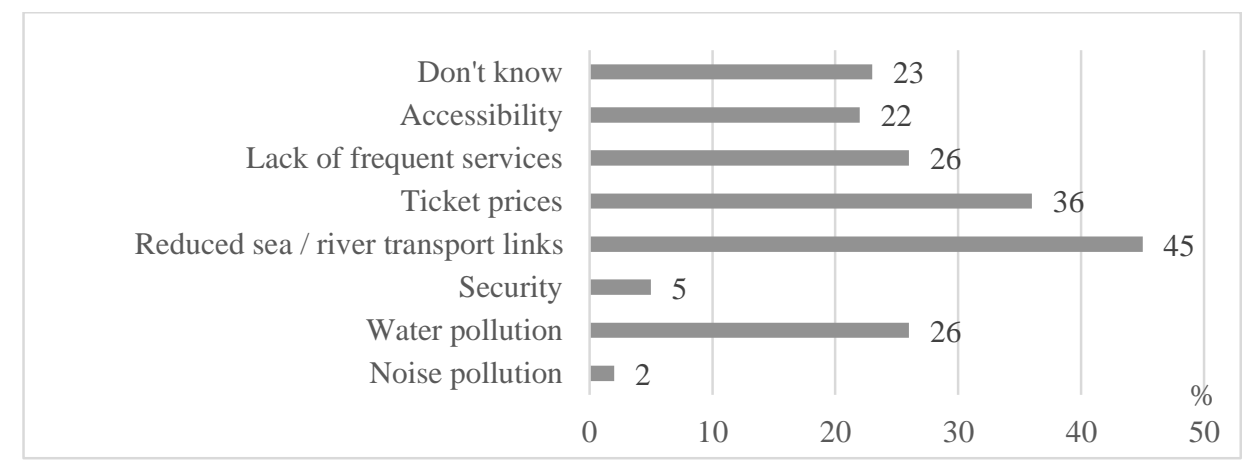

The analysed mobility patterns and travel behaviour of Croatian citizens provides insight into transportation system quality (supply, services, problems etc.). There is an obvious car-dominance in everyday mobility, as well as in tourism travel. The highly positive perception of road traffic could be an indication of potential problems in the future, as the other sectors will not be able to compete adequately with road traffic (problematic modal split due to supply shortcomings). The negative effects of car-dominance in Croatia are primarily noticeable in road congestion (73\%). A lack of connections and ticket cost are repeatedly pointed out as problematic areas of other individual transport sectors (rail, sea/river, air). The respondents' insufficient knowledge is evident with 
ToSEE - Tourism in Southern and Eastern Europe, Vol. 5, pp. 621-640, 2019

N. Slavić, E. Mrnjavac: HOW SMART IS THE MOBILITY OF CROATIAN CITIZENS? BEHAVIOUR ...

regard to air and water-based transportation. Maintenance is considered an issue (and a priority) in road and rail transportation.

Level of service is an important determinant of travel behaviour. Although based on the perception of residents, the identified shortcomings of the Croatian transportation system affect the potential tourism transportation supply and travel patterns, as discussed in the following section.

\section{DISCUSSION: THE IDENTIFIED TRANSPORTATION SYSTEM'S DETERMINANTS AND TOURISM TRANSPORTATION SUPPLY}

Mobility mode choice is affected by a variety of factors (Van Acker et al. 2011), for example income (Ribeiro et al. 2014), and is therefore a complex managerial issue. Despite the high share of everyday car-mobility of Croatian citizens in 2018, the share of PT and walking (the alternative modes of urban mobility) are a notable part of the modal split. Comparison with the 2014 data (TNS Opinion \& Social Network 2014) for Croatia shows a slight but positive change of mobility patterns of behaviour (car $-4 \%$, train $+1 \%$, PT $+5 \%$, walking $+1 \%$ ) - table 4 . Therefore, alternative urban mobility conditions are considered to be (slowly) improving. A decrease in car-dominance and an increase in alternative modes is also a path recognized by European cities aimed at improving quality of life (e.g. Sustainable Urban Mobility Plan of Barcelona (Ajuntament de Barcelona n.d.). Alternatives to cars are a significant part of urban tourism transportation supply (more mobility options for sightseeing, for example).

Table 4: Mode of transport used most often on a typical day

\begin{tabular}{|c|c|c|c|c|c|c|c|}
\hline Year & Car & $\begin{array}{c}\text { Motorbike } \\
\text { / moped }\end{array}$ & Train & Ship / boat & $\begin{array}{c}\text { Urban } \\
\text { public } \\
\text { transport }\end{array}$ & Bicycle & Walking \\
\hline 2014 & 51 & 1 & 0 & 0 & 21 & 6 & 18 \\
\hline 2018 & 47 & 1 & 1 & 0 & 26 & 5 & 19 \\
\hline
\end{tabular}

Urban planning is crucial in creating compact surroundings (Hickman et al. 2013) aimed at reversing the trend to alternative modes of transport. Restrictions on car traffic parallel to improving PT service and conditions of active mobility need to be systematically implemented. The Croatian modal split indicates that action is needed to support primarily bicycle traffic ( $-1 \%$ in 2018 compared to 2014).

The identified change in everyday mobility (2014-2018) could be attributed to the reasons for using a certain travel mode (table 5). Those reasons reflect the various changes in the immediate surroundings. The increased share of "there is no alternative" indicates shortcomings of traffic system management. In other words, the lack of modal choice in any destination limits free movement of both the local population and visitors. Available travel options (at least two) are key to sustainable urban mobility management. 
ToSEE - Tourism in Southern and Eastern Europe, Vol. 5, pp. 621-640, 2019

N. Slavić, E. Mrnjavac: HOW SMART IS THE MOBILITY OF CROATIAN CITIZENS? BEHAVIOUR ...

Table 5: The reasons for using the selected everyday transport mode in Croatia $(\%)$

\begin{tabular}{|c|c|c|c|c|c|c|c|c|}
\hline Year & Price & $\begin{array}{c}\text { Enviro- } \\
\text { nment }\end{array}$ & $\begin{array}{c}\text { Secu- } \\
\text { rity }\end{array}$ & $\begin{array}{c}\text { Conve- } \\
\text { nience }\end{array}$ & Speed & $\begin{array}{c}\text { Available } \\
\text { facilities }\end{array}$ & $\begin{array}{c}\text { There is } \\
\text { no } \\
\text { alternative }\end{array}$ & Other \\
\hline 2014 & 22 & 3 & 9 & 71 & 30 & 13 & 3 & 5 \\
\hline 2018 & 20 & 7 & 4 & 45 & 45 & 24 & 27 & 2 \\
\hline
\end{tabular}

Transportation needs of international tourists are met by accessibility-based transport planning while the generic dimensions of transport services (affordability, accessibility, availability, safety, comfort) and socio-demographic characteristics of tourists influence their transport choices (Nutsugbodo et al. 2018). By selecting the factors that would encourage PT usage (graph 2) the respondents created a provisional checklist for transportation planners in envisioning more competitive PT service and responding to the challenges of causative factors mentioned earlier. The combination of service frequency, more available tickets and better spatial coverage would act as an incentive to using PT (more frequently) for tourists as well. Contradictory to the fast technological development in all sectors of human life, survey results imply the lack of recognition for 'soft' measures that enable easier and more efficient travel (planning) - supportive to better traffic system management, like: the ability to buy tickets online, availability of online PT route planners, availability of mobile applications with timetables, and other services information. Travel tools (like Maas) or applications (e.g. Innovative Urban Transportation Apps for 2019 (Meeting of the Minds 2019)) support tourism transportation demand management, enabling the usage of different mobility modes individually or combined. The travel apps market is extensive and urban destinations show more recognition of their potential in facilitating easier travel and better managing traffic systems.

Journeys of $300 \mathrm{~km}$ and more potentially represent tourism travel. Social and economic changes occurring after Croatia formally became an EU member state are well represented with the increase in the number of longer journeys that Croatian residents took in 2018 (graph 8). The factors influencing outbound travel could also be evaluated in the context of the inbound movement of people. Simplified border crossing procedures and economic stability are inviting for international tourists. 
ToSEE - Tourism in Southern and Eastern Europe, Vol. 5, pp. 621-640, 2019

N. Slavić, E. Mrnjavac: HOW SMART IS THE MOBILITY OF CROATIAN CITIZENS? BEHAVIOUR ...

Graph 8: The number of journeys of $300 \mathrm{~km}$ or more within the EU (including Croatia) in the 12 months previous to research - comparison of 2014 (TNS Opinion \& Social Network 2014) and 2018 data

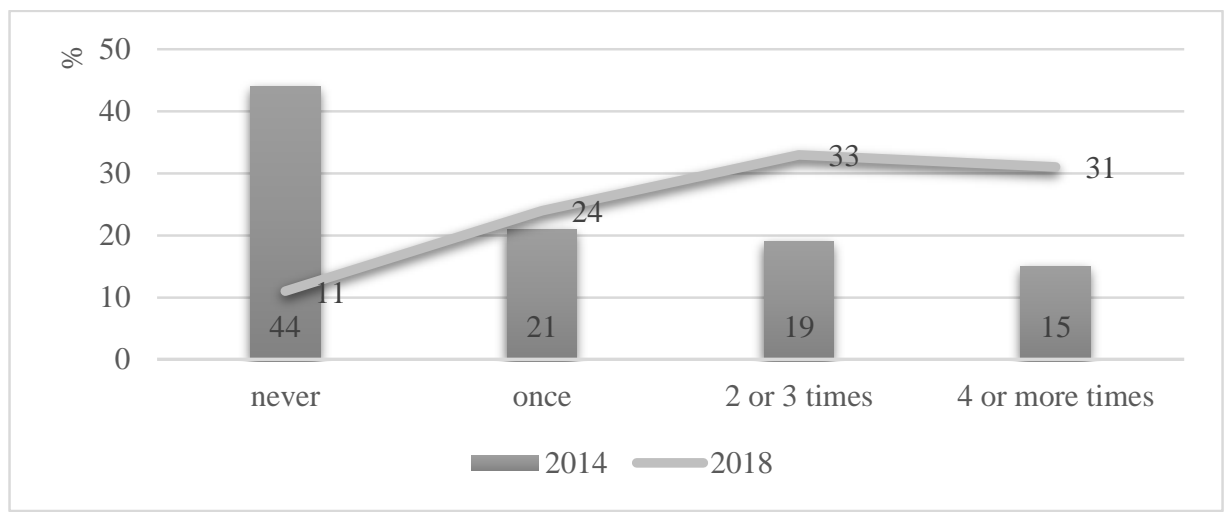

Car-dominance in journeys of $300 \mathrm{~km}$ and more could to an extent be attributed to the good national motorway network, everyday mobility habits and the (lack of) quality of other transportation sectors. The primary mode choice on longer journeys (car and coach) confirms that longer distance travel (including tourism-motivated journeys) is dominated by road traffic. The lacking offering of other sectors and the lack of knowledge about air and water-based travel options (of surveyed citizens) would suggest an underdeveloped transportation market (supply) in Croatia. Nevertheless, growth in incoming tourist numbers paints a different picture.

Longer travel mode choice is influenced by speed, convenience and price, although in a changing order compared with 2014 (table 5). In its current state, the national rail service cannot compete with road traffic in any of the above factors. Although it would be mostly faster than automobile transportation, air transport is considered expensive.

Table 5: The reasons for using the selected mode(s) of transport for a journey of $300 \mathrm{~km}$ or more - comparison of 2014 and 2018 data (\%)

\begin{tabular}{|c|c|c|c|c|c|c|c|}
\hline Year & Price & Environment & Security & Convenience & Speed & $\begin{array}{c}\text { Available } \\
\text { facilities }\end{array}$ & $\begin{array}{c}\text { There is } \\
\text { no } \\
\text { alternative }\end{array}$ \\
\hline 2014 & 23 & 1 & 8 & 73 & 44 & 10 & 1 \\
\hline 2018 & 26 & 1 & 5 & 50 & 56 & 17 & 19 \\
\hline
\end{tabular}

As far as the quality of individual transportation subsystems in Croatia in the last 5 years is concerned, respondents show the same positive or negative attitude-orientation towards a certain mode as they did in 2014. However, the significantly larger share of Croatian citizens who chose the statement "stayed the same" in 2018 demonstrates the lack of quality improvements in all modes of transportation (table 6). The lack of information availability is also a significant factor in evaluating and using air and waterbased transportation. 
ToSEE - Tourism in Southern and Eastern Europe, Vol. 5, pp. 621-640, 2019

N. Slavić, E. Mrnjavac: HOW SMART IS THE MOBILITY OF CROATIAN CITIZENS? BEHAVIOUR ...

Table 6: Comparison of transportation sector quality (services, connections, infrastructure etc.) in Croatia in the last 5 years $(\%)$

\begin{tabular}{|c|c|c|c|c|c|c|}
\hline Year & $\begin{array}{c}\text { Improved a } \\
\text { lot }\end{array}$ & $\begin{array}{l}\text { Somewhat } \\
\text { improved }\end{array}$ & $\begin{array}{c}\text { Somewhat } \\
\text { deteriorated }\end{array}$ & $\begin{array}{c}\text { Deteriorated a } \\
\text { lot }\end{array}$ & $\begin{array}{l}\text { Stayed } \\
\text { the } \\
\text { same }\end{array}$ & $\begin{array}{l}\text { Don't } \\
\text { know }\end{array}$ \\
\hline \multicolumn{7}{|c|}{ Air transport } \\
\hline 2014 & 14 & 37 & 9 & 2 & 7 & 31 \\
\hline 2018 & 10 & 34 & 2 & 1 & 23 & 30 \\
\hline \multicolumn{7}{|c|}{ Rail transport } \\
\hline 2014 & 3 & 21 & 32 & 21 & 8 & 15 \\
\hline 2018 & 1 & 10 & 22 & 19 & 25 & 22 \\
\hline \multicolumn{7}{|c|}{ Road transport } \\
\hline 2014 & 13 & 56 & 17 & 2 & 9 & 3 \\
\hline 2018 & 22 & 48 & 5 & 3 & 20 & 2 \\
\hline \multicolumn{7}{|c|}{ Sea or river transport } \\
\hline 2014 & 4 & 32 & 16 & 2 & 11 & 35 \\
\hline 2018 & 1 & 17 & 4 & 2 & 33 & 43 \\
\hline
\end{tabular}

The attitude of Croatian citizens towards road traffic quality reflects the national road traffic network development in the last 15 years. The decrease in the share of negative perception reflects better perceived service quality, spatial coverage and availability. Accessible destinations (and the majority of tourists that come by car) are good for the Croatian economy but, when other transportation sectors lag behind in quality, the national traffic system cannot be long-term sustainable, smart or green as a whole. Freight being transported on roads being less of an issue in 2018 (table 7) has positive repercussions in the context of the tourist experience. On the other hand, citizens' experiences demonstrate that the issues of air pollution, safety and missing links need to be better managed in the near future, to prevent them from becoming as serious a problem as congestion (during the tourist season).

Table 7: Comparison of road transport problems perception in 2014 and 2018 (\%)

\begin{tabular}{|c|c|c|c|c|c|c|c|}
\hline Year & $\begin{array}{c}\text { Road } \\
\text { conge- } \\
\text { stion }\end{array}$ & $\begin{array}{c}\text { Noise } \\
\text { pollu- } \\
\text { tion }\end{array}$ & $\begin{array}{c}\text { Air } \\
\text { pollu- } \\
\text { tion }\end{array}$ & $\begin{array}{c}\text { Secu- } \\
\text { rity }\end{array}$ & $\begin{array}{c}\text { Missing } \\
\text { road } \\
\text { links }\end{array}$ & $\begin{array}{c}\text { Road } \\
\text { mainte- } \\
\text { nance }\end{array}$ & $\begin{array}{c}\text { The amount of } \\
\text { freight being } \\
\text { transported by } \\
\text { road }\end{array}$ \\
\hline 2014 & 40 & 11 & 16 & 33 & 10 & 66 & 22 \\
\hline 2018 & 73 & 11 & 23 & 39 & 19 & 58 & 15 \\
\hline
\end{tabular}

Rail transport is historically significant in European travel but its infrastructural restrains on service attractiveness in Croatia limit its role in tourism travel. Passenger trains being late, is a major issue in the almost non-existing share of trains in the modal split in everyday mobility and tourism travel. Rail traffic being under national governance in Croatia and the market monopole/lack of competition of Croatian Railways do not justify the decades of insufficient development, missing modernisation and neglecting contemporary passengers' needs. Consequently, the ecological and traffic safety benefits of this transport mode are not recognized, in general and in tourism. 
ToSEE - Tourism in Southern and Eastern Europe, Vol. 5, pp. 621-640, 2019

N. Slavić, E. Mrnjavac: HOW SMART IS THE MOBILITY OF CROATIAN CITIZENS? BEHAVIOUR ...

The problems Croatian citizens attach to air transport reflect poor knowledge on (lowcost carrier) services and the lack of spatial coverage (i.e. small number of available airports for international travel in general). Nevertheless, the identified air transport problems influence mostly national travel behaviour. In other words, rising numbers of tourists choose air transport when travelling to Croatia. Although air travel services are more available during the tourist season, improvements in the sector are still needed as the sector is inflexible (infrastructural shortcomings and the limited number of destinations to choose from).

The indentation of the Croatian coast results in the inevitable use of sea transportation means. The limited demand in everyday travel of the local population multiplies during the tourist season and although this research indicates potential dissatisfaction with ticket prices (subsidised) and lack of service frequency out of the peak season, service limitations do not seem to affect tourist demand for most popular island destinations. Even more limited in transportation service supply, river transport is restricted to a few Croatian ports. Nevertheless, the passenger numbers of the Vukovar and Osijek Port Authority indicate growing river cruise demand. The poor state of infrastructure and services in air and river transportation sectors (in relation to road traffic) does not seem to discourage but rather limits the tourist transportation supply. Nevertheless, the lack of information availability is more evident on the national market and affects those travel patterns.

Tourism transportation planning requires effective tourism transportation infrastructure management (Cheuk et al. 2010; Kaldiyarov et al. 2017). Tourism transportation infrastructure incorporates means of transportation, transportation sites, transportation routes, travel ways, and services, service and tourism facilities on transportation sites and in the vicinity of transportation routes, and information media (Page 2011 as cited in Kaldiyarov et al. 2017). In the context of the existing traffic management modus operandi and the level of social development and long-term needs, the recorded transportation quality perceptions offer guidelines for authorities and traffic planners in traffic policy development (improvements) and its implementation. As previously stated, the sustainability of mobility/travel patterns is largely influenced by traffic system supply and the service quality of each individual transportation system. The problems of each individual travel sector are important also for tourism because transportation is an inevitable part of every travel experience.

\section{CONCLUSION}

Mobility management or transportation demand management measures are being implemented in an effort to reduce the negative side-effects of car-dominated everyday mobility. Unfortunately, research results indicate that Croatian destinations lack a systematic approach to transportation system management. There are cities in Croatia awarded for smart mobility (Poslovni dnevnik 2018), but until every aspect of city functioning is digitized and technologically supported in solving urban (transportation) problems, those cities cannot be perceived as smart. 
ToSEE - Tourism in Southern and Eastern Europe, Vol. 5, pp. 621-640, 2019

N. Slavić, E. Mrnjavac: HOW SMART IS THE MOBILITY OF CROATIAN CITIZENS? BEHAVIOUR ...

As far as the total Croatian transportation system is concerned, road-transport dominance in everyday mobility and tourism-related travel (inbound and outbound) is not long-term sustainable nor does it concur with transportation demand management requirements. Tourism transportation supply needs to be based on all traffic sectors. For Croatian tourism transportation this implies significant improvements in air, water-based and rail services. Although this paper identifies the shortcomings of the (tourism) transportation system, there are also positive changes occurring in Croatia in providing transportation services for both citizens and visitors.

The analysis of local population behaviour is considered a valuable transportation system supply indicator, although tourism transportation behaviour recognizes additional influences on travel patterns. "Smart" in the context of this paper is used as a synonym for long-term transportation sustainability based on managing mobility and transportation demand, primarily by using communicative measures and implementing technological innovations.

\section{RESEARCH LIMITATIONS}

Although the sample size is considered adequate, the sample type (convenient sample) is potentially restrictive in forming conclusions for the whole population. Additionally, lack of more information on sample demographics is considered a limitation to a certain extent. This research deliberately gathered only the data on age, place of residence (the county), and the employment status of the respondents because of the large number of questions (16) respondents needed to answer about their travel behaviour.

The interviewers were directed to disperse their efforts in order to ensure appropriate age and regional representation in the research. Nevertheless, convenience sampling led to unequal regional coverage and the respondents profile described in table 1 . This could partially be justified by obvious national centralization (approx. 1/4 of the Croatian population lives in the nation's capital) and irregular regional population dispersion.

The European Commission offers no newer Eurobarometer on the topic, other than the one from 2014. It is therefore not possible to compare these research results to the European average in 2018. Nevertheless, it is possible to identify the changes in the behaviour of Croatian citizens in the period from 2014 (data from Eurobarometer) to 2018 (data from this research). Also, the Eurobarometer data are rounded off to a whole number so the slight changes in behaviour (and the changes of mobility patterns are gradual) are not visible. Nevertheless, due to replicating the approach of the Special Eurobarometer, the authors considered it appropriate to act accordingly in order to have comparable data in the four-year period (2014-2018).

While recognizing its potential limitations, this research helps fill the gap in analysing Croatian population mobility in urban surroundings in the context of mobility management and sustainability of the current situation, having in mind that the majority of urban settlements are also important tourist destinations. The research results interpreted in the paper offer an insight into the level of sustainability or, in other words, the level of smart of Croatian tourist destinations. 
ToSEE - Tourism in Southern and Eastern Europe, Vol. 5, pp. 621-640, 2019

N. Slavić, E. Mrnjavac: HOW SMART IS THE MOBILITY OF CROATIAN CITIZENS? BEHAVIOUR ...

\section{ACKNOWLEDGEMENTS}

This paper has been financially supported by the University of Rijeka, for the project ZP UNIRI 5/18.

\section{REFERENCES}

Ajuntament de Barcelona, n.d., About Us: Urban Mobility Plan, viewed 18 December 2018, https://www.barcelona.cat/mobilitat/en/about-us/urban-mobility-plan

Alkay, E. (2011), "The Residential Mobility Pattern in the Istanbul Metropolitan Area”, Housing Studies, Vol. 26, No. 4, pp. 521-539. https://doi.org/10.1080/02673037.2011.559752

Axhausen, K.W. (2007), "Concepts of Travel Behavior Research", in Gärling Tommy L.S. (Ed.), Threats from Car Traffic to the Quality of Urban Life, Elsevier, New York, pp. 165-185.

Brdulak, H. and Brdulak, A. (2015), "Smart city solutions in regard to urbanization processes - Polish cases", Logistics \& Sustainable Transport, Vol. 6, No. 1, pp. 50-60. https://doi.org/10.1515/jlst-2015-0011

Bucher, D., Mangili, F., Cellina, F., Bonesana, C., Jonietz, D. and Raubal, M. (2019), "From location tracking to personalized eco-feedback: A framework for geographic information collection, processing an visualization to promote sustainable mobility behaviors", Travel Behaviour and Society, Vol. 14 pp. 43-56. https://doi.org/10.1016/j.tbs.2018.09.005

Calabrese, F., Diao, M., Di Lorenzo, G., Ferreira, J.Jr. and Ratti, C. (2013), "Understanding individual mobility patterns from urban sensing data: A mobile phone trace example", Transportation Research Part C: Emerging Technologies, Vol. 26, pp. 301-313. https://doi.org/10.1016/j.trc.2012.09.009

Chang, J.S.K. and Hsu, Y.T. (2014), "Smart Travel and Sustainable Mobility for Green Transport Cities", Re Imagining Urban Mobility, New Cities Foundation, Geneva.

Cheba, K. and Saniuk, S. (2016), "Urban mobility - identification, measurement and evaluation", Transportation Reasearch Procedia, Vol. 14, pp. 1230-1239. https://doi.org/10.1016/j.trpro.2016.05.194

Cheng, L., Chen, X., De Vos, J., Lai, X. and Witlox, F. (2019), “Applying a random forest method approach to model travel mode choice", Travel Behavour and Society, Vol. 14, pp. 1-10. https://doi.org/10.1016/j.tbs.2018.09.002

Cheuk, S., Liew-Tsonis, J., Phang Ing, G. and Razli, A.I. (2010), “An Establishment Of The Role Of Private And Public Sector Interests In The Context Of Tourism Transport Planning And Development: The Case Of Malaysia”, International Business \& Economics Research Journal, Vol. 9, No. 2, pp. 59 67.

Decker, B., Hećimović, H. and Wolek, M. (2012), "Sustainable Urban Mobility Planning in Central Eastern Europe: case examples from Poland and Croatia", Procedia - Social and Behavioral Sciences, Vol. 48, pp. 2748-2757. https://doi.org/10.1016/j.sbspro.2012.06.1244

Dias, J.A., da Silva, L.M.C. and de Morais, T.C. (2014), "Urban mobility to improve the center of a Brazilian historic town”, Procedia - Social and Behavioral Sciences, Vol. 160, pp. 170-177. https://doi.org/10.1016/j.sbspro.2014.12.128

ELTIS (2018a), ELTIS: Mobility Plans, The SUMP concept, viewed 27 January 2019, http://www.eltis.org/mobility-plans/sump-concept.

ELTIS (2018b), Eltis: Mobility Plans, viewed 30 November 2018 http://www.eltis.org/mobility-plans/member-state/croatia.

Enoch, M. (2012), Sustainable Transport, Mobility Management and Travel Plan, Ashgate Publishing Limited, Surrey, England.

European Commission (2010), Europe2020: A European strategy for smart, sustainable and inclusive growth European Commission, Brussels, Belgium.

European Commission (2011), Roadmap to a Single European Transport Area - Towards a competitive and resource, European Commission, Brussels, Belgium.

European Commission (2013), A Concept For Sustainable Urban Mobility Plans (Annex to Together towards competitive and resource-efficient urban mobility), European Commission, Brussels, Belgium.

European Commission (2016), Analysing the potential for wide scale role out of integrated Smart Cities and Communities solutions, European Commission, Brussels, Belgium.

European Commission (2019a), Clean transport, Urban transport, viewed 22 March, https://ec.europa.eu/transport/themes/urban/urban_mobility_en. 
ToSEE - Tourism in Southern and Eastern Europe, Vol. 5, pp. 621-640, 2019

N. Slavić, E. Mrnjavac: HOW SMART IS THE MOBILITY OF CROATIAN CITIZENS? BEHAVIOUR ...

European Commission (2019b), Public Opinion, viewed 22 February, http://ec.europa.eu/commfrontoffice/publicopinion/index.cfm/General/index.

European Platform on Mobility Management (EPOMM), n.d., Mobility Management: a Definition, viewed 13 November 2018, http://www.epomm.eu/index.php?id=2590.

European Union (2011), White Paper 2011 Roadmap To A Single European Transport Area, EU.

Fuji, S. and Taniguchi, A. (2006), "Determinants of the effectiveness of travel feedback programs - a review of communicative mobility management measures for changing travel behaviour in Japan", Transport Policy, Vol. 13, pp. 339-348. doi: 10.1016/j.tranpol.2005.12.007

Gonzales, M.C., Hidalgo, C.A. and Barabasi, A.-L. (2008), "Understanding individual human mobility patterns", Nature, Vol. 453, No. 5, pp. 779-782.

Grieco, M. (2015), "Social sustainability and urban mobility: shifting to a socially responsible pro-poor perspective", Social Responsibility Journal, Vol. 11, No. 1, pp. 82-97. https://doi.org/10.1108/SRJ05-2014-0061

Hickman, R., Hall, P. and Banister, D. (2013), "Planning more for sustainable mobility", Journal of Transport Geography, Vol. 33, pp. 210-219.

Hoyer, K.G. (2000), "Sustainable Tourism or Sustainable Mobility? The Norwegian Case", Journal of Sustainable Tourism, Vol. 8, No. 2, pp. 147-160. https://doi.org/10.1080/09669580008667354

Jarass, J. and Heinrichs, D. (2014), "New urban living and mobility", Transportation Research Procedia, Vol. 1, pp. 142-153. https://doi.org/10.1016/j.trpro.2014.07.015

Jason Chang, S.K. and Hsu, Y.T. (2014), "Smart Travel and Sustainable Mobility for Green Transport Cities", Re-imagining Urban Mobility, New Cities Fundation, Geneva.

Jones, P. (2014), "The evolution of urban mobility: The interplay of academic and policy perspectives", IATSS Research, Vol. 38, pp. 7-13. https://doi.org/10.1016/j.iatssr.2014.06.001

Kaldiyarov, D.A., Kassymova, A.M., Mussina, T.S., Korabayeva, N.B. and Berkinbayeva, Y.E. (2017), “An Investigation into Scientific Methodological Foundations of Transportation Infrastructure in the Tourism Industry", Journal of Environmental Management and Tourism, Vol. 8, No. 24, pp. 1529 1533. https://doi.org/10.14505/jemt.v8.8(24).08

Kamargianni, M., Li, W., Matyas, M. and Schaefer, A. (2016), “A critical review of new mobility services for urban transport", Transportation Research Proceedia, Vol. 14, pp. 3294-3303. https://doi.org/10.1016/j.trpro.2016.05.277

Keseru, I., Bulckaen, J. and Macharis, C. (2016), "Sustainable, Participatory and Practical: the NISTO evaluation framework for urban and regional mobility projects", Transportation Research Procedia, Vol. 13, pp. 134-144. https://doi.org/10.1016/j.trpro.2016.05.014

Lindenau, M. and Böhler-Baedeker, S. (2014), "Citizen and stakeholder involvement: a precondition for sustainable urban mobility", Transportation Research Procedia, Vol. 4, pp. 347-360. https://doi.org/10.1016/j.trpro.2014.11.026

Macedo, J., Rodrigues, F. and Tavares, F. (2017), "Urban sustainability mobility assessment: indicator proposal", Energy Procedia, Vol. 134, pp. 731-740. https://doi.org/10.1016/j.egypro.2017.09.569

Marlina, E. and Natalia, D.A.R. (2017), "Land Transportation and Tourism Development", International Journals of Economic Perspectives, Vol. 11, No. 2, pp. 542-554.

Meeting of the Minds (2019), Innovative Urban Transportation Apps for 2019, viewed 10 January 2019, https://meetingoftheminds.org/12-innovative-urban-transportation-apps-4708.

Meyer, M.D. (1999), "Demand management as an element of transportation policy", Transportation Research Part A: Policy and Practice, Vol. 33, No. 7, pp. 575-599.

Morfoulaki, M., Mitsakis, E., Chrysostomou, K. and Stamos, I. (2011), "The contribution of urban mobility management to trip planning and the environmental upgrade of urban areas", Procedia, Vol. 20, pp. 162-170. https://doi.org/10.1016/j.sbspro.2011.08.021

Mrnjavac, E. and Slavić, N. (2018), "Mobility of citizens of Croatia: experiences and attitutdes, with special reference to tourism", Acta Turistica, Vol. 30, No. 2, pp. 129-154. https://doi.org/10.22598/at/2018.30.2.129

Nutsugbodo, R.Y., Amenumey, E.K. and Mensah, C.A. (2018), "Public transport mode preferences of international tourists in Ghana: Implications for transport planning", Travel Behaviour and Society, Vol. 11, pp. 1-8. https://doi.org/10.1016/j.tbs.2017.11.002

Okraszewska, R., Romanowska, A., Wolek, M., Oskarbski, J., Birr, K. and Jamroz, K., (2018), "Integration of a Multilevel Transport System Model into Sustainable Urban Planning”, Sustainability, Vol. 10, No. 479. https://doi.org/10.3390/su10020479

Palma Lima, J., da Silva Lima, R. and da Silva, A.N.R. (2014), "Evaluation and selection of alternatives for the promotion of sustainable urban mobility", Procedia - Social and Behavioral Sciences, Vol. 162 pp. 408-418. https://doi.org/10.1016/sbspro.2014.12.222 
ToSEE - Tourism in Southern and Eastern Europe, Vol. 5, pp. 621-640, 2019

N. Slavić, E. Mrnjavac: HOW SMART IS THE MOBILITY OF CROATIAN CITIZENS? BEHAVIOUR ...

Poslovni dnevnik (2018), Pametni gradovi 2018, viewed 1 November 2018 , http://www.poslovni.hr/specijal/pametni-gradovi-2018.

Priester, R., Miramontes, M. and Wulfhorst, G. (2014), “A generic code of urban mobility: how can cities drive future sustainable development?”, Transportation Research Procedia, Vol. 4, pp. 90-102. https://doi.org/10.1016/j.trpro.2014.11.008

Przybylowski, A. (2018), "Sustainable urban mobility planning: Gdynia city case study", Ekonomia $i$ prawo/Economics and Law, Vol. 17, No. 2, pp. 195-209. https://doi.org/10.12775/EiP.2018.014

Ribeiro, G.R., Magrinyà, F. and Orrico Filho, D.R. (2014), "Study of the changes in urban mobility of the Brazilian middle class brought about by the population's increased income and the ensuing impact on urban mass transit", Procedia - Social and Behavioural Sciences, Vol. 160, pp. 294-303. https://doi.org/10.1016/j.sbspro.2014.12.141

Ritchie, H. and Roser, M. (2019), Urbanization, OurWorldInData.org.

Serna, A., Gerrikagoitia, J.K., Bernabé, U. and Ruiz, T. (2017), "Sustainability analysis on Urban Mobility based on Social Media content", Transportation Research Procedia, Vol. 24, pp. 1-8. https://doi.org/10.1016/j.trpro.2017.05.059

TNS Opinion \& Social (2014), Special Eurobarometer 422a “Quality of Transport”, European Commission, Brussels, Belgium.

United Nations (2018), World Urbanization Prospects: The 2018 Revision (key facts), viewed 22 December 2018, https://population.un.org/wup/Publications/.

Van Acker, V., Mokhtarian, P. L. and Witlox, F. (2011), "Going soft: on how Subjective Variables Explain Modal Choices for Leisure Travel", European Journal of Transport and Infrastructure Research, Vol. 11, No. 2, pp. 115-146.

Wang, Z., He, S.Y. and Leung, Y. (2018), “Applying mobile phone data to travel behaviour research: A literature review", Travel Behaviour and Society, Vol. 11, pp. 141-155. https://doi.org/10.1016/j.tbs.2017.02.005

World Economic Forum (2017), World Economic Forum Annual Meeting, viewed 22 January 2019, https://www.weforum.org/press/2017/02/global-rise-of-cities-poses-challenge-to sutainableurban-development/.

Zavaglia, C. (2016), "European Union instruments and strategies for sustainable urban mobility: Exploiting PUMS and ITS to develop an efficient car sharing proposal", Proceedia - Social and Behavioral Sciences, Vol. 223, pp. 542-548. https://doi.org/10.1016/j.sbspro.2016.05.337

Zhang, Y., Martens, K. and Long, Y. (2018), "Revealing group travel behavior patterns with public transit smart card dana", Travel Behaviour and Society, Vol. 10, pp. 42-52. https://doi.org/10.1016/j.tbs.2017.10.001

Nataša Slavić, $\mathrm{PhD}$, Assistant Professor

University or Rijeka

Faculty of Tourism and Hospitality Management

Department of Logistics and Tourism Resources

Primorska 42, 51410 Opatija, Croatia

Phone: +385-51-294188

E-mail: natasa.slavic@fthm.hr

Edna Mrnjavac, PhD, Full Professor

University or Rijeka

Faculty of Tourism and Hospitality Management

Department of Logistics and Tourism Resources

Primorska 42, 51410 Opatija, Croatia

Phone: +385-51-294188

E-mail: ednam@fthm.hr 